Article

\title{
Decision-Making of Green Space Utilization and Protection in Urban Fringe Based on Biodiversity Trade-Off
}

\author{
Haijiao Liu ${ }^{1,2}$, Yonghong Ma ${ }^{1, *}$, Qing Liu ${ }^{2,3}$ and Yan Song ${ }^{2, *}$ \\ 1 School of Economics and Management, Harbin Engineering University, Harbin 150001, China; \\ liuhaijiao@hrbeu.edu.cn \\ 2 Department of City and Regional Planning, University of North Carolina at Chapel Hill, Chapel Hill, \\ NC 27517, USA; 16b334017@hit.edu.cn \\ 3 School of Architecture, Harbin Institute of Technology, Key Laboratory of Cold Region Urban and Rural \\ Human Settlement Environment Science and Technology, Ministry of Industry and Information Technology, \\ Harbin 150030, China \\ * Correspondence: mayonghong@hrbeu.edu.cn (Y.M.); ys@email.unc.edu (Y.S.)
}

Received: 13 January 2020; Accepted: 12 February 2020; Published: 13 February 2020

\begin{abstract}
Urbanization leads to the continuous expansion of urban built-up areas and the erosion of green space in urban fringe areas, leading to the continuous decline of biodiversity. Urban planners and managers need corresponding decision support tools to coordinate the contradiction between the utilization and protection of green space, ensure the maintenance capacity of biodiversity in green space, and realize the sustainable development of regional economy, society and ecology. Therefore, based on the Hellwig Method, this study designed a decision-making method of green space utilization and protection in urban fringe areas and applied the method to the decision simulation of single or multiple green space utilization and protection modes. In the decision simulation of a green space utilization mode, we evaluated the $\mathrm{H}_{k}$ values of one or several green space sample units, respectively. The smaller the $\mathrm{H}_{\mathrm{k}}$ value, the smaller the influence of the green space unit on the biodiversity maintenance function of the whole green space in the region, so the green space unit can be selected first when making green space utilization planning decisions in the urban fringe. In the decision simulation of green space protection mode, the higher the $\mathrm{H}_{\mathrm{k}}$ value of single green space sample unit combination or multiple green space sample unit combination, the greater the influence of the green space unit in the combination on the maintenance function of the overall green space biodiversity in the region. Then, when planning the green space protection in the urban fringe, the combination of such green space sample units should be given priority as the key protection and control objects. As a decision support tool for optimal scheme of green space utilization and protection in urban fringe areas, the method is practical, instructive, reasonable, operable, flexible, and universal.
\end{abstract}

Keywords: urban and rural sustainable development; biodiversity conservation; green space planning; decision support tool; Hellwig Method

\section{Introduction}

The world is becoming more and more urbanized. From 2000 to 2030, the area of the global urban built-up areas will triple [1], mainly occupying the green space at the urban fringe [2,3]. According to the data of China's Land Planning Outline (2016-2030), from 2000 to 2015, the built-up areas in cities and towns in China increased by about 113\%, and the erosion of green space in fringe areas caused biodiversity decline [4]. With the implementation of the strategy of building a new socialist countryside 
and revitalizing the countryside in the 21st century, the expectation of providing other goods and services in the green space in the suburbs of cities is getting higher and higher $[5,6]$.The development and construction activities of green space, represented by the leisure and entertainment functions, cultural landscape functions, and health protection functions of rural land use, have been continuously strengthened $[7,8]$, promoting the continuous transformation, development, and utilization of various functions of green space land use in urban fringe areas [9]. As we all know, green space has a variety of positive impacts on the quality of life, health, and well-being of human beings. It not only has the functions of economic production, land support, aesthetics, leisure, and entertainment [10-12] but also provides potential habitats for species and has the function of maintaining biodiversity $[13,14]$. Therefore, under the background of rapid urbanization and the development mode diversification of green space in urban fringe areas, urban planning and managers need corresponding decision support tools to coordinate the contradiction between the utilization and protection of green space, ensure the maintenance capacity of biodiversity in green space, and realize the sustainable development of regional economy, society, and ecology.

At present, the international research on the utilization and protection of green space mainly focuses on urban development space demarcation and control area of green space delineation. In the demarcation of urban development space, green space utilization is included, the main criterion is the suitability of land development, the area suitable for land development is demarcated as urban construction space or reserved space for urban development (for example, the boundary of urban spatial growth is demarcated), the main functional area of development is planned, or the appropriate urban development area is demarcated [15-17]. In the delineation of a green space control area, the main criteria is the importance of ecosystem function, a green space with important ecosystem functions is classified as an ecological protection areas or prohibited or restricted construction area, such as the construction of the green belt around the city [18-20], the designation of ecological protection area or ecological restoration area $[14,21]$, and the building of ecological security pattern and ecological network, etc. [22-24]. On the one hand, current research mainly focuses on the theoretical construction of the overall ecological security pattern of green space and the protection and restoration of its ecological functions. Few studies pay attention to the practical process of using or transforming green space units one by one in the development of human society and economy. The research and practice process ignores the pre-assessment of impacts of green space unit utilization or conservation schemes on the ecological environment. The lack of relevant decision-making and evaluation methods result in less effective control and protection of green space in actual operation, which restricts the coordinated development of regional social economy and ecology. On the other hand, the current research points out that the urban green space not only provides support services and cultural services for the development of human society, such as the supply of city construction space, aesthetic and recreational space, but also provides biodiversity maintenance services for a variety of species, such as the providing of potential habitat, foraging, breeding and other survival and activity space [11-14,25]. Therefore, in the context of the rapid development of global urbanization and biodiversity conservation actions, urban green space planning and management decisions should not only meet the needs of urban development space, but also meet the needs of species habitat.

In view of this phenomenon, this study used a decision-making method for the utilization and protection of green space at the urban fringe, and, based on the measurement of biodiversity loss or conservation, it provides a decision support tool for the selection of the optimal scheme for the utilization or protection of single or multiple green space units in urban fringe, so as to minimize the loss of biodiversity in the decision-making of green space utilization in the urban fringe and maximize the conservation of biodiversity in the decision-making of green space protection in the urban fringe. This study provides theoretical basis and technical support for the planning and management decision-making of green space utilization and protection in urban fringe areas, so as to ensure the coordination of social and economic development with human welfare and ecological protection. In order to achieve the above research objectives, this study is carried out from the following aspects: 
The first part answers the scope and composition of green space on the urban fringe and what is the theoretical basis for evaluating the biodiversity maintenance function of green space units. The second part answers how to measure the degree of biodiversity loss or conservation of regional green space caused by different planning and site selection schemes in the decision-making of utilization and protection of green space units in urban fringe areas. According to this schema, the optimal scheme for the utilization or protection of green space in the urban fringe is determined. In the third part, the application simulation research of two planning modes is carried out based on this method. The fourth part discusses the application and practicality of this method and summarizes the results.

\section{Theoretical Basis}

\subsection{Connotation and Identification of Green Space on the Urban Fringe}

At present, academic circles have not formed a unified understanding of the connotation and identification of green spaces. Looking at the current research results, the common feature of green space is a regional space mainly covered by vegetation that provides a variety of natural ecological, social, and economic service functions. This study summarizes the natural research results, and the main differences lie in the narrow and broad sense, the urban and rural, and the natural and artificial [26,27].

\subsubsection{Differentiation between Narrow Sense and Broad Sense}

In a narrow sense, green space is a regional space dominated by vegetation coverage, providing a variety of natural ecological, social, and economic service functions. It is divided into cultivated land, garden, forest land, grassland, wetland, and wasteland according to different vegetation coverage types. The broad sense green space includes not only the composition form of the narrow green space, but also the space relatively open, semi-closed, or with few space limiting elements enclosed by the narrow green space, such as parks, gardens, streets, squares, alleys, courtyards, scenic spots, etc., which have many important functions such as ecology, entertainment, culture, history, and landscape.

\subsubsection{Differentiation between Urban and Rural}

Urban green space mainly includes parks, squares, waterfront, and other open spaces formed by the enclosure or combination of trees, shrubs, hedges, flower beds, grasslands, and other vegetation within the urban built-up areas. This also includes areas with good greening environment such as water source protection areas, nature reserves, wildlife parks, and various tourist attractions, which have positive effects on urban ecology, landscape, and residents' leisure life. Rural green space is a green space recognized from the perspective of city area or region. It is an expansion of urban green space, including all kinds of cultivated land, garden plot, forest land, grassland, wetland, wasteland, etc. within the region, which have direct or indirect value to improve urban and rural ecological environment and ensure people's production and life. Rural green space plays an important role in coordinating the development structure of urban and rural land, improving the ecological system, alleviating the disorderly expansion of cities, and maintaining the sustainable development of urban and rural environment. Urban green space is mostly in broad green space, while rural green space is mostly in narrow green space.

\subsubsection{Differentiation between Nature and Artificial}

According to the degree of human participation in the construction of green space, green space can be divided into natural green space, semi-natural green space and artificial green space. Urban green space is mostly in artificial green space, while rural green space is mostly in natural and semi-natural green space. 


\subsubsection{Green Space on the Urban Fringe}

The urban fringe is a discontinuous regional entity formed at a specific stage of urban development, which is close to the urban built-up area. It is an area where the urban built-up area extends to the surrounding vast agricultural land integration and gradual change [28]. Broadly speaking, it is divided into three levels-urban suburbs, municipal districts, and affected areas. Among them, urban suburbs are administrative construction areas close to urban built-up areas and are divided into three circles-near, middle, and far. Municipal districts are several county-level administrative units around the central city divided according to administrative divisions. The affected area refers to the development area when the economy and city scale of a large city radiate to a part of cities and towns outside the jurisdiction of the city. In a narrow sense, it refers to the annular zone within a certain range around the urban built-up area, which can also be regarded as the first layer in the broad urban fringe area in the spatial category and is usually called the "urban-rural fringe" [29].

The green space scope of the urban fringe defined in this study is an area with the basic boundary of the urban built-up area as the inner boundary and the boundary of the urban planning area as the outer boundary. It is mainly located in the narrow urban fringe. The main reasons are as follows. First, this area is located between the city and the township, where rich human activities and diverse natural processes are highly integrated, and it is a zone where the economic, social and environmental functions of land use are drastically transformed $[10,30]$. Second, this area belongs to the restricted construction area in the urban planning space control area, and the use of green space in such urban fringe areas needs to coordinate the relationship between utilization and protection. Third, defining the scope of urban fringe with the basic boundaries of urban built-up areas and the boundaries of urban planning areas is convenient for unified cognition, identification, and extraction of green space in urban fringe areas.

Based on the above research and analysis, it can be seen that the green space formed in the urban fringe is a compound green space system with both narrow sense and broad sense, urban and rural, natural and artificial characteristics, and is a complex open system with high coupling of "nature, society, and economy." It mainly includes cultivated land, forest land, garden plot, grassland, wetland, wasteland, and scenic land (including various water source protection areas, nature reserves, wildlife parks, country parks, etc.).

\subsection{Theoretical Basis for Evaluation of Biodiversity Maintenance Function of Green Space Units}

Land, as the basic material carrier of green space in urban fringe areas, provides potential habitats for various species through the maintenance function of land use biodiversity [27-29], which belongs to the subcategory of ecological maintenance function in the multi-function of land use. As we all know, land use/land cover change is one of the main determinants that have a significant impact on global ecosystems, global biogeochemistry, climate change, and human vulnerability [31]. There is an intricate relationship between land use function change and land cover change [32]. Land use function change is the result of land cover change and the main driving factor that determines future land cover change. The Millennium Ecosystem Assessment once pointed out the need to pay special attention to the link between land cover change and ecosystem functions [33]. Therefore, the biodiversity maintenance function of green space is closely related to the biodiversity maintenance function of land use, and further related to the composition and change of land cover. Costanza estimated the value of ecological services per unit area of ecosystems under different land cover types. The results showed that wetland was the most valuable service for maintaining biodiversity, followed by grassland, farmland and forest were the third and fourth, and rivers/lakes and deserts were 0 [34]; Wang Zongming calculated and measured the relationship between land use diversity and ecosystem service changes based on information entropy and landscape index. The results show that the richer the land use types, the more significant the ecosystem service function [35], and relevant studies prove that landscape composition diversity is a sign of biodiversity [36]. To sum up, the maintenance function of land use biodiversity is closely related to the diversity of land cover types and compositions, which not 
only directly affects the maintenance function of land use biodiversity but also indirectly determines the quality of potential habitats provided by green space in urban fringe areas. Therefore, this study takes the area, species, diversity, and abundance of land cover types as an indirect reflection of the biodiversity maintenance function of green space units.

However, relevant studies suggest that a single observation of land cover is not enough to explain the land use function [37]. In many case studies, the same land cover will produce different land use functions, and vice versa. Therefore, it is not sufficient to quantify the land use function based on the land cover information alone, and the reflection on the actual situation of the land use function is limited [38]. It needs to integrate other information related to land use and land cover to assess the actual situation of land use function, such as socio-economic statistics and environmental conditions such as accessibility, land cover, landscape and soil status. For such non-commodity production functions as land use soil and water conservation function, biodiversity maintenance function and landscape aesthetics, such functions mainly come from the characteristics of land use system, including landscape structure, land use history, and spatial layout of land use system across landscapes [39]. The actual assessment of such land use functions needs to be combined with relevant information. In addition, relevant studies show that the evaluation of land use biodiversity maintenance function should consider both the stability and quality of patches and the impact of external environment [39-44]. Most studies based on the comprehensive evaluation method to evaluate the maintenance function of patch biodiversity, and select the corresponding indicators from patch quality, connectivity, ecosystem service function, ecological sensitivity, patch response to the outside world, etc. [3,6,14,24]. Based on the above research results, this study mainly constructs an evaluation index system from the following three levels to evaluate the actual situation of land use biodiversity maintenance function: Firstly, the stability of land cover patches is considered at the landscape structure level. Secondly, consider the current quality of land cover patches at the historical level of land use. Thirdly, considering the stress caused by other land use system spatial layout at the level of cross-landscape land use system spatial layout, referring to the evaluation results of biodiversity maintenance function grade of land use patches, and taking it as a direct reflection of biodiversity maintenance function of green space units.

\subsection{Research on Green Space Utilization and Protection Decision Methods}

The decision-making of green land utilization and protection is one of the decision-making problems of sustainable utilization and management of resources, such as the index evaluation method, multi-objective optimization algorithm based on genetic algorithm. For example, Psomas et al., based on the SWAT model, simulated and evaluated the impact of different agricultural water management methods in the basin on water-energy-land-food related monitoring indicators, and selected the optimal agricultural water use and management method based on the impact assessment results [45]; Panagopoulos $\mathrm{Y}$ et al., evaluated the cost-effectiveness of irrigation and fertilization practices management in reducing agricultural water consumption and surface runoff pollution in different catchment locations to optimize agricultural best management practices(BMPs) selection and allocation, with economic and environmental trade-offs [46]. In addition, some studies make planning decisions based on the integrity of green space structure, mainly using landscape analysis method (using remote sensing data and GIS technology) and non-built-up area design model to improve the landscape connectivity or restore ecological function of green space [47-49]. Based on the band protection planning method, the patch-network conceptual planning method and the graph theory method, the green belt around the city [18-20], the ecological protection area or the ecological restoration area [13,14,21], the ecological security pattern and the ecological network are constructed [22-24]. Based on the land suitability evaluation method, the boundary delineation of urban spatial growth, the planning of main functional areas and urban green space layout are carried out $[15,16,50]$. In addition, Luis et al., based on cellular automata model, simulated the possible spatial pattern of land use in the future according to the current law of urban land spatial development, as well as the possible development trend and policy direction, so as to formulate or adjust the corresponding land use policies and 
schemes [51]. In conclusion, although there are more decision-making tools for sustainable utilization and management of resources in academia, they have not been applied to decision-making of green space utilization and protection. Moreover, the latter two planning decision-making methods cannot simultaneously evaluate the possible impacts of different green space utilization or protection schemes. The above research results indicate the direction of this study-that is, we should seek for a new green space utilization and protection decision-making method, so as to realize the comparison of different utilization or protection schemes, under the set goal, and then choose the optimal scheme in a compromise. According to the description of the problem in the instruction section, the status quo of biodiversity maintenance function of each green space unit involved in different schemes should be taken as explanatory variables, while the overall status quo of biodiversity maintenance function of regional green space should be taken as explanatory variables. From a mathematical point of view, it needs to solve which explanatory variable (the biodiversity maintenance function of the regional overall green space) has the greatest impact on the explained variable (the biodiversity maintenance function of the regional overall green space). In order to answer this question, this study applies Hellwig's Optimal Selection Prediction Model [52] to solve this problem, which is referred to as Hellwig Method for short. This method has been applied to the study of species biodiversity measurement and ecological significance of green space in the city of Lublin, Poland [53]. The main data is the small mammal composition and abundance. This study shows that the data about actual species composition and abundance is lost and difficult to obtain in most of China's small cities and small towns, which increases the difficulty to study the biodiversity maintenance function of green space in small cities or small towns in China. Therefore, based on the above theory that land cover diversity can fully reflect biodiversity, this study uses land cover data to replace the actual species data, and uses Hellwig Method to establish the decision model of green space utilization and protection.

\section{Methods}

This research method mainly includes two steps, as shown in Figure 1. The first step is basic data preprocessing, and the main content is based on the above-mentioned green space biodiversity maintenance function evaluation theory. On the one hand, the area of various land cover types, land cover types, land cover diversity index (LCDI) and index of green space unit participation in regional land cover richness (PRLCI) in the internal composition of green space units are selected as indirect indicators to measure the biodiversity maintenance function of green space units. On the other hand, the evaluation index system of land use biodiversity maintenance function is constructed, and the biodiversity maintenance function grade of each land use patch is determined. The highest grade of land use patch biodiversity maintenance function in the internal composition of the green space unit is taken as the direct reflection of the biodiversity maintenance function of the green space unit. The second step is data analysis. The main content is to take the calculation results of the indirect measurement index and the direct measurement index of the green space unit biodiversity maintenance function of the first step as the indicative basic data to comprehensively reflect the biodiversity maintenance function of the green space unit, input into the decision-making model of green space utilization or protection in the urban fringe, and determine the optimal scheme of green space utilization or protection in the urban fringe according to the measurement of biodiversity loss or conservation degree of regional green space by different schemes. 


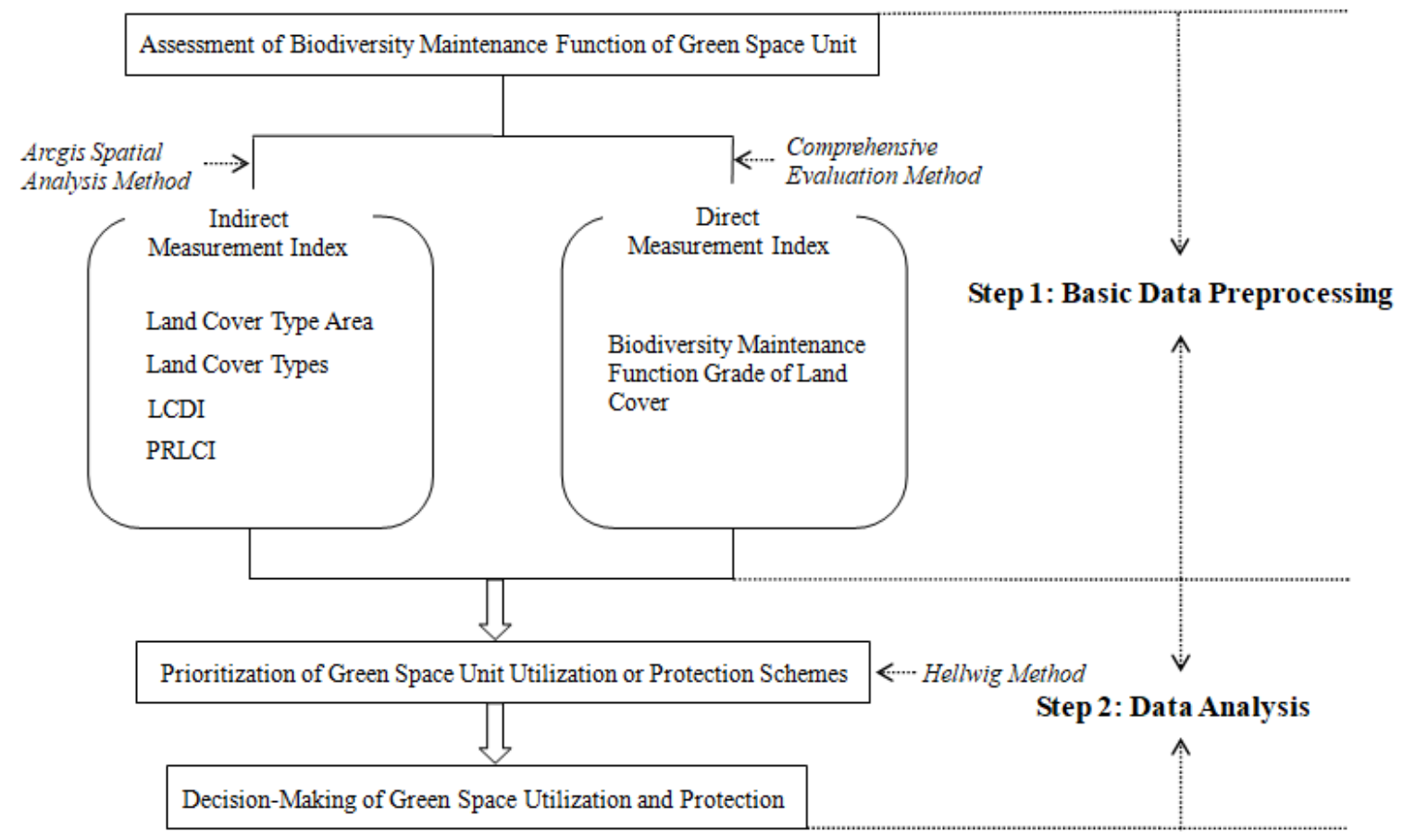

Figure 1. Global methodological diagram.

\subsection{Step 1: Basic Data Preprocessing}

3.1.1. Calculation Method of Indirect Measurement Index for Biodiversity Maintenance Function of Green Space Unit

Land cover type area refers to the area of various land cover types included in the green space unit. Land cover types refer to the number of land cover types contained in green space units; The calculation method of LCDI index is derived from Shannon-Wiener Species Diversity Index, and the calculation method of PRLCI index is derived from the Index of Patch Participation in Urban Species Richness [46]. Based on the spatial data calculation function of Arcgis software, the above four indexes are calculated respectively. And the calculation formulas of LCDI index and PRLCI index are as follows:

$$
\begin{gathered}
L C D I=-\sum_{i=1}^{m} p_{i} \lg p_{i} \\
\text { PRLCI }=\sum_{i=1}^{m} \frac{a_{i}}{A_{i}^{2}}
\end{gathered}
$$

where $i$ represents the $i$-th land cover type, $m$ represents the number of land cover types, $p_{i}$ represents the proportion of the $i$-type land cover to the total land cover area of the green space unit, $a_{i}$ represents the area of the $i$-th land cover type of the green space unit, and $A_{i}$ represents the total area of the $i$-th land cover type in the regional green space.

The LCDI index is equal to the proportion of each land cover type in the total land cover area in the green space unit multiplied by its logarithm, and then summed up to take negative values, with LCDI $\geq 0$ and no upper limit. The PRLCI index is equal to the contribution of land cover types and areas of green space units to the overall land cover abundance of the regional green space, and the overall land cover abundance of the regional green space $=$ the total number of land cover types/the total area of the regional green space. 
3.1.2. Calculation Method of Direct Measurement Index for Biodiversity Maintenance Function of Green Space Unit

In this study, 16 evaluation factors were selected from three criteria levels of land cover patch stability, land cover patch quality and land cover patch stress (as shown in Table 1). The 0-1 standardization method is used to standardize each index, then the entropy weight method is used to determine the index weight, and the comprehensive evaluation method is combined to evaluate the biodiversity maintenance function of green space. Based on the comprehensive evaluation results, we use the natural breakpoint method to divide the maintenance function of green space biodiversity in the study area into 1-9 levels, and the higher the level, the more significant the maintenance function of green space biodiversity. The main calculation process and formula are as follows:

Step 1: Standardization of evaluation indicators: $P_{i j}=\left(X_{i j}-\min \left(X_{i j}\right)\right) /\left(\max \left(X_{i j}\right)-\min \left(X_{i j}\right)\right)$

Step 2: Calculate the entropy value of $\mathrm{j}$-th index: $E_{j}=-k \sum_{i=1}^{n} P_{i j} \ln P_{i j}$, let $k=1 / \ln n$

Step 3: Calculate the weight of $\mathrm{j}$-th index: $W_{j}=\left(1-E_{j}\right) /\left(m-\sum_{j=1}^{m} E_{j}\right)$

Step 4: The comprehensive evaluation expression is: $F_{m}=W_{1} P_{i j}+W_{2} P_{i j}+\cdots+W_{j} P_{i j}$

where $P_{i j}$ is the value obtained after standardization of evaluation index; $X_{i j}$ is the actual value of the evaluation index; $i=1,2, \ldots, n ; j=1,2, \ldots, m ; n$ is the number of samples, which indicates the number of patches in this paper. $m$ is the number of evaluation indexes. 
Table 1. Evaluation index system of biodiversity maintenance function in green space.

\begin{tabular}{|c|c|c|c|}
\hline Target Layer (A) & Criteria Layer (B) & Indicator Layer (C) & Ecological Significance \\
\hline \multirow{16}{*}{$\begin{array}{l}\text { Biodiversity maintenance } \\
\text { function of green space }\end{array}$} & \multirow{5}{*}{ Land cover patch stability } & Patch area $(+)$ & $\begin{array}{c}\text { The larger the patch area, the more species it can accommodate and the higher } \\
\text { the biodiversity. }\end{array}$ \\
\hline & & Patch area/Total area $(+)$ & $\begin{array}{l}\text { Its value restricts the abundance, quantity, food chain, and reproduction of secondary } \\
\text { species of this type of patch as habitat. }\end{array}$ \\
\hline & & Edge density $(+)$ & $\begin{array}{l}\text { It reflects the fragmentation degree of the landscape, and its size directly affects the edge } \\
\text { effect and species composition. }\end{array}$ \\
\hline & & Fractal dimension $(+)$ & $\begin{array}{l}\text { It reflects the complexity of patch edge structure on a certain observation scale. } \\
\text { The smaller the value, the stronger the patch self-similarity. }\end{array}$ \\
\hline & & Shape index (+) & $\begin{array}{l}\text { The larger the index, the more complex the shape, and the easier it is to connect with the } \\
\text { outside world, indicating that the closer the connection, the more stable the habitat is. }\end{array}$ \\
\hline & \multirow{7}{*}{ Land cover patch quality } & Slope grade $(-)$ & $\begin{array}{c}\text { The greater the slope, the less suitable for living organisms, and easier to occur soil } \\
\text { erosion or other geological disasters. }\end{array}$ \\
\hline & & Climate production potential $(+)$ & $\begin{array}{l}\text { The higher the climatic production potential, the higher the biological yield or } \\
\text { agricultural yield that may be obtained per unit area of land. }\end{array}$ \\
\hline & & Vegetation cover index $(+)$ & $\begin{array}{c}\text { The vegetation cover index is represented by NDVI. The larger the value, the better the } \\
\text { vegetation health and the higher the habitat quality. }\end{array}$ \\
\hline & & Water conservation amount $(+)$ & $\begin{array}{l}\text { The greater the oxygen content in the water source, the stronger the ability of land cover } \\
\text { landscape patches to replenish groundwater, slow down the seasonal fluctuation of river } \\
\text { flow, detain flood and replenish dry water, and ensure water quality. }\end{array}$ \\
\hline & & Eco-service value equivalent $(+)$ & The higher the value equivalent of patch ecological services, the richer the biodiversity. \\
\hline & & Ecological footprint (+) & $\begin{array}{c}\text { The greater the ecological footprint, the greater the degree of sustainable development of } \\
\text { natural assets. }\end{array}$ \\
\hline & & Distance from river $(+)$ & $\begin{array}{l}\text { The closer to the river, the more favorable it is for animals and plants to multiply } \\
\text { and migrate. }\end{array}$ \\
\hline & \multirow{4}{*}{ Land cover patch stress } & Distance from settlement (-) & $\begin{array}{l}\text { The closer the distance to the residential area, the greater the negative effect of human } \\
\text { disturbance on the habitat. }\end{array}$ \\
\hline & & Distance from high speed/rail (-) & $\begin{array}{c}\begin{array}{c}\text { The closer the distance to the high-speed/railway, the greater the negative effect of human } \\
\text { disturbance on the habitat. }\end{array}\end{array}$ \\
\hline & & Distance from highway (-) & $\begin{array}{l}\text { The closer to the national highway, the greater the negative effect of human disturbance } \\
\text { on habitat. }\end{array}$ \\
\hline & & Distance from mining site $(-)$ & The closer to the mining site, the greater the negative effect on the habitat. \\
\hline
\end{tabular}




\subsection{Step 2: Data Analysis}

The Hellwig Method was first published in United Nations Education, Scientific and Cultural Organization (UNESCO) project "Quantitative Index System of Human Resources Development Composition" [52]. Before the arrival of the computer era, due to the limitation of large amount of calculation and difficulty in calculation, this method was mainly used in econometrics and simple problem analysis with few variables. Later, thanks to the birth of computers and the application of various software, this method was gradually applied in ecology and other research backgrounds [54]. In this study, land cover type area, land cover type, LCDI index, PRLCI index and the highest level of biodiversity maintenance function are used as indicators to evaluate the biodiversity maintenance function of each green space unit, and are introduced into the calculation of Hellwig Method explanatory variable information carrying capacity $h_{k j}$ index. On this basis, the $H_{k}$ index of the overall information carrying capacity of the explanatory variable combination is calculated. The higher the value, the greater the correlation between the explanatory variable and the explained variable, that is, the stronger the correlation between the biodiversity maintenance function of the green space unit combination and the biodiversity maintenance function of the overall green space in the region, and the greater the contribution of the green space unit combination to the biodiversity maintenance function of the overall green space in the region. Taking the principle of minimizing biodiversity loss or maximizing biodiversity conservation as the principle of green space utilization or protection, the optimal scheme of green space utilization or protection in urban fringe area is determined by comparing the $H_{k}$ values of different combinations of green space utilization or protection schemes. The technical route is shown in Figure 1. And the basic calculation steps and formulas are as follows:

Step (1): If there are green space units $X_{1}, X_{2}, \ldots, X_{n}, n$ representing the number of green space units, the number of green space non-empty possibility combinations is $(L), L=2 n-1$.

Step (2): For each green space unit in combination $k$, the calculation formula of land cover type area, land cover type, LCDI index, PRLCI index and biodiversity maintenance function grade index information carrying capacity $\left(h_{\mathrm{kj}}\right)$ is as follows:

$$
h_{k j}=\frac{r_{j}^{2}}{\sum_{l \in I_{k}}\left|r_{l j}\right|}, l \in I_{k}
$$

where $k$ represents the sequence number of each green space combination $(1 \leq k \leq L), I_{\mathrm{k}}$ represents the number of green space units contained in the green space combination $k, j$ represents the serial number of information carrying capacity of a single green space unit, $r_{\mathrm{j}}$ represents the correlation coefficient between a single green space unit and each index of the overall green space of the region, and $r_{l j}$ represents the correlation coefficient between each green space in the combination $k$.

Step (3): Based on the calculation of the single index information carrying capacity $\left(h_{\mathrm{kj}}\right)$ of the green space combination $k$, the overall carrying capacity $\left(H_{k}\right)$ of the green space combination $k$ can be obtained, and the value range of $H_{\mathrm{k}}$ is [0,1], and the calculation method is as follows:

$$
H_{k}=\sum_{j=1}^{I_{k}} h_{k j}
$$

Standardize the $H_{k}$ index. In order to compare and explain the $H_{k}$ index values in a green space combination, we use the following formula to solve the problems of inconsistent index units and so on.

$$
100 \times \frac{H_{k}-H_{k \min }}{H_{k \max }-H_{k \min }}
$$

where $H_{k \min }$ represents the lowest value of $H_{k}$ in each green space combination analyzed, and $H_{k \max }$ represents the highest value of $H_{k}$ in each green space combination analyzed. In this formula, the value 
range of $H_{k}$ is $[0,100]$, and 100 means that the biodiversity maintenance function of the green space combination is highly correlated with the biodiversity maintenance function of the overall green space in the region, that is, the green space combination plays a vital role in the biodiversity maintenance function of the overall green space in the region.

\section{Application Simulation}

\subsection{Overview of the Study Area}

In this study, the planning scope of Beian City (county) in Heilongiiang Province is taken as the application simulation research area of the method. The city represents the characteristics of urban spatial development in which small towns in northern China have taken the road of centralized urbanization in the past 10 years, with new industries gathering in built-up areas, traditional industries transferring to peripheral areas, real estate driving capital gathering in space, and urban construction land expanding continuously. Similar to the urbanization of many cities in the world, urban development extends to urban suburbs and takes up various forms of green space in urban suburbs. As a result, the biodiversity in the region is decreasing and ecosystem services are declining. Green space use and conservation decision-making methods are urgently needed to monitor and assess the impact of a range of green space development activities on biodiversity. In 2010, the construction land in Beian's built-up area was about 23.32 square kilometers. By 2020, the construction land in the built-up area is expected to reach 33.28 square kilometers, and the urban construction land area will expand by about $50 \%$ within 10 years. In 2010, the urbanization rate of Beian City was about $60 \%$, and by 2020 , the urbanization rate will be about $65 \%$. In addition to construction land, land cover types are mainly composed of cultivated land, garden plot, grassland, forest land, and wasteland covered by local vegetation, providing living and activity space for the flora and fauna.

\subsection{Data Sources}

The data mainly include land use remote sensing image data, digital elevation data, vegetation cover data and other relevant statistical data. The current data of land use mainly comes from the interpretation of remote sensing images of land use in 2017. Topographic and geomorphological data come from 2017 digital elevation data processing; Relevant data of vegetation cover come from NDVI value calculation of MODIS remote sensing images in 2017. In addition, there are relevant text and picture data of "Beian City Master Plan (2006-2020)." The calculation of climate production potential and water conservation refers to the Technical Guide for Delineation of Ecological Protection Red Line. The regional ecological service value is revised based on the relevant research results of Costanza [34], Xie Gaodi and others [55], and finally the ecological service value per unit area of various types of land is calculated. The calculation method of ecological footprint supply is calculated according to the ecological footprint supply model proposed by Bai Yucui [48]. Other data are obtained by spatial analysis and calculation function of Arcgis software, which is designed and developed by Esri company in the US.

\subsection{Application Mode}

Looking at the current projects related to green space planning and management in urban fringe areas in China, it mainly involves two decision-making modes-green space utilization planning in urban fringe areas and green space protection planning in urban fringe areas. In the decision-making of green space utilization in urban fringe areas, the goal is to minimize the loss of biodiversity. In the decision-making of green space protection in urban fringe areas, the goal is to maximize biodiversity conservation. Based on the Decision-Making Method of Green Space Utilization and Protection in Urban Fringe under the Balance of Biodiversity Loss and Conservation, it can be flexibly applied to the decision-making of green space planning and management in urban fringe. According to the amount of green space utilized or protected, it can be divided into single green space utilization or protection 
mode decision and multiple green space utilization or protection mode decision. In this study, two scenarios of representative utilization and protection are set up: the spatial site selection planning of construction land in urban fringe and the ecological source protection planning of urban fringe.

\subsubsection{Decision Simulation of Single or Multiple Green Space Utilization Modes}

In the recent planning and construction, at the cost of minimizing biodiversity loss, this study selects one or more green space units from the annual reserved space development units in the urban fringe as new industrial district, residential district or commercial district for development. For multiple green space utilization scenarios, this study sets that $25 \%$ of the total number of reserved green space units will be used for land development and construction. In this scenario, it is necessary to evaluate the impact of removing one or more green space units in the sample green space on the biodiversity maintenance function of the overall green space in the region, so as to determine the spatial location of construction land.

\subsubsection{Decision Simulation of Single or Multiple Green Space Protection Modes}

In the long-term planning, one or more ecological source protection areas are planned in the urban fringe with the goal of maximizing biodiversity conservation. Similarly, for multiple green space protection situations, this study sets $25 \%$ of the total green space of the sample as the ecological source for protection. In this scenario simulation, one or more green spaces that play the most important role in maintaining the biodiversity of the overall green space in the current region will be selected as priority protection and control objects.

\subsection{Application Simulation Results}

The green space in the city area of the study area mainly includes 11 types of land cover, including dry land, irrigated land, paddy field, orchard, other garden plots, forested land, shrub forest land, other forested land, natural pasture land, other grassland and scenic land, as shown in Figure 2. According to the "Suburban Planning" data in the "Beian City Master Plan 2006-2020," 16 green space units are selected by stratified random sampling from the suitable construction area (within the suburban area) to the restricted/forbidden construction area (outside the suburban area to within the planning area) as the method application simulation sample space, and the sample distribution and its basic characteristics are shown in Figure 3 and Table 2. The data preprocessing results of 16 green space sample units and the overall green space within the city area for land cover type area, land cover type, LCDI index, PRLCI index and relevant indicators with the highest level of biodiversity maintenance function are shown in Table 3. It contains 17 columns, the first 16 columns respectively correspond to 16 green space sample unit data, and the last column is the overall green space data within the city area, indicating the biodiversity maintenance function level of the overall green space within the current city area.

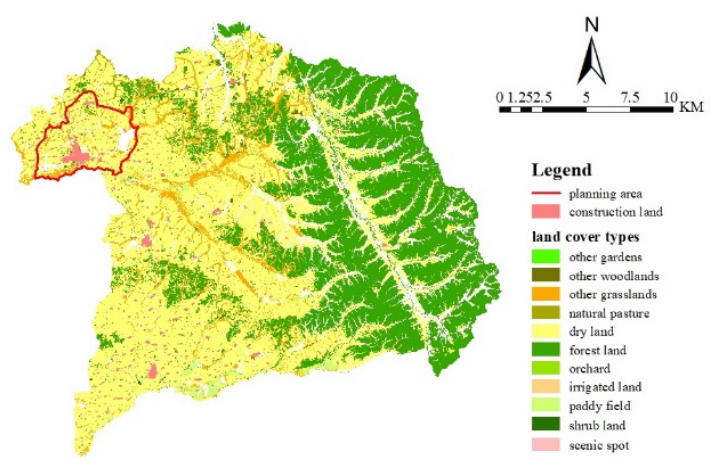

Figure 2. Current situation map of land cover type in Beian city (county). 


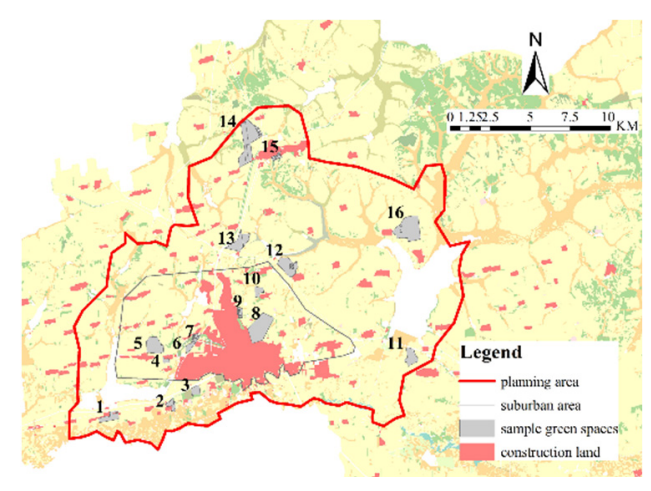

Figure 3. The distribution of ecological space samples within the planning area of Beian City.

Table 2. The location of the green space sample unit, the types of land cover it contains and the type of suburban plan subdivision it belongs to.

\begin{tabular}{|c|c|c|c|}
\hline Location & $\begin{array}{l}\text { Sample Unit } \\
\text { Number }\end{array}$ & Types of Land Cover It Contains & $\begin{array}{l}\text { Types of Suburban Plan Subdivision It } \\
\text { Belongs to }\end{array}$ \\
\hline \multirow{2}{*}{ Outskirts } & 1 & Dry land & Ecological conservation area (Forbidden area) \\
\hline & 2 & Dry land, Forest land, Other grassland & Ecological conservation area (Forbidden area) \\
\hline \multirow{5}{*}{$\begin{array}{l}\text { Downtown } \\
\text { vicinity }\end{array}$} & 4 & Dry land & Planned built-up areas \\
\hline & 5 & Dry land & Planned built-up areas \\
\hline & 8 & Dry land, Scenic spots & Planned built-up areas \\
\hline & 9 & Dry land, Other grassland & Planned built-up areas \\
\hline & 10 & Dry land, Other grassland & Suitable construction area \\
\hline \multirow{4}{*}{ Outskirts } & 11 & Dry land, Other grassland & Water source protection area (Forbidden area) \\
\hline & 12 & Dry land, Shrub land, Other woodland, Other grassland & Water source protection area (Forbidden area) \\
\hline & 13 & Dry land, Forest land, Other grassland & $\begin{array}{c}\text { Ecological landscape restoration area } \\
\text { (Restricted area) }\end{array}$ \\
\hline & 16 & Dry land, Forest land, Other grassland & Water source protection area (Forbidden area) \\
\hline
\end{tabular}


Table 3. Basic data preprocessing

\begin{tabular}{|c|c|c|c|c|c|c|c|c|c|}
\hline \multirow{3}{*}{$\begin{array}{l}\text { Indicative Indicators of Biodiversity } \\
\text { Maintenance Function in Green Space }\end{array}$} & \multicolumn{9}{|c|}{ Green Space Sample Code (No.) } \\
\hline & 1 & 2 & 3 & 4 & 5 & 6 & 7 & 8 & 9 \\
\hline & \multicolumn{9}{|c|}{ Numeric Status of Biodiversity Indicative Indicators } \\
\hline Dryland area $\left(\mathrm{km}^{2}\right)$ & 0.466798 & 0.237846 & 0.270340 & 0.111997 & 0.906517 & 0.193750 & 0.079584 & 1.411620 & 0.166854 \\
\hline Irrigated land area $\left(\mathrm{km}^{2}\right)$ & 0 & 0 & 0 & 0 & 0 & 0 & 0.000041 & 0 & 0 \\
\hline Paddy field area $\left(\mathrm{km}^{2}\right)$ & 0 & 0 & 0 & 0 & 0 & 0 & 0 & 0 & 0 \\
\hline Orchard area $\left(\mathrm{km}^{2}\right)$ & 0 & 0 & 0 & 0 & 0 & 0 & 0 & 0 & 0 \\
\hline Other garden area $\left(\mathrm{km}^{2}\right)$ & 0 & 0 & 0 & 0 & 0 & 0 & 0 & 0 & 0 \\
\hline Forest area $\left(\mathrm{km}^{2}\right)$ & 0 & 0.001765 & 0.000465 & 0 & 0 & 0 & 0 & 0 & 0 \\
\hline Shrub land area $\left(\mathrm{km}^{2}\right)$ & 0 & 0 & 0 & 0 & 0 & 0.000007 & 0.051919 & 0 & 0 \\
\hline Other woodland area $\left(\mathrm{km}^{2}\right)$ & 0 & 0 & 0.000049 & 0 & 0 & 0 & 0 & 0 & 0 \\
\hline Natural pasture area $\left(\mathrm{km}^{2}\right)$ & 0 & 0 & 0 & 0 & 0 & 0 & 0 & 0 & 0 \\
\hline Other grassland area $\left(\mathrm{km}^{2}\right)$ & 0 & 0.020925 & 0 & 0 & 0 & 0.000008 & 0.052813 & 0 & 0.009969 \\
\hline Scenic spots area $\left(\mathrm{km}^{2}\right)$ & 0 & 0 & 0 & 0 & 0 & 0 & 0 & 0.352124 & 0 \\
\hline Types of land cover composition & 1 & 3 & 3 & 1 & 1 & 3 & 4 & 2 & 2 \\
\hline Biodiversity maintenance function level & 3 & 1 & 2 & 2 & 3 & 2 & 1 & 4 & 1 \\
\hline LCDI index & 0.0000 & 0.1306 & 0.0046 & 0.0000 & 0.0000 & 0.0004 & 0.4688 & 0.0002 & 0.0959 \\
\hline PRLCI index & $3.89 \times 10^{-14}$ & $1.15 \times 10^{-13}$ & $1.89 \times 10^{-13}$ & $9.33 \times 10^{-15}$ & $7.55 \times 10^{-14}$ & $7.47 \times 10^{-14}$ & $4.10 \times 10^{-10}$ & $8.46 \times 10^{-8}$ & $5.94 \times 10^{-14}$ \\
\hline \multirow{3}{*}{$\begin{array}{l}\text { Indicative Indicators of Biodiversity } \\
\text { Maintenance Function in Green Space }\end{array}$} & \multicolumn{7}{|c|}{ Green Space Sample Code (No.) } & \multirow{3}{*}{ City Area } & \\
\hline & 10 & 11 & 12 & 13 & 14 & 15 & 16 & & \\
\hline & \multicolumn{7}{|c|}{ Numeric Status of Biodiversity Indicative Indicators } & & \\
\hline Dryland area $\left(\mathrm{km}^{2}\right)$ & 0.265145 & 0.596251 & 0.930704 & 0.849828 & 2.114082 & 0.124254 & 1.912879 & 3463.452548 & \\
\hline Irrigated land area $\left(\mathrm{km}^{2}\right)$ & 0 & 0 & 0 & 0 & 0 & 0 & 0 & 1.718874 & \\
\hline Paddy field area $\left(\mathrm{km}^{2}\right)$ & 0 & 0 & 0 & 0 & 0 & 0 & 0 & 64.379526 & \\
\hline Orchard area $\left(\mathrm{km}^{2}\right)$ & 0 & 0 & 0 & 0 & 0 & 0 & 0 & 0.324005 & \\
\hline Other garden area $\left(\mathrm{km}^{2}\right)$ & 0 & 0 & 0 & 0 & 0 & 0 & 0 & 1.418857 & \\
\hline Forest area $\left(\mathrm{km}^{2}\right)$ & 0 & 0 & 0 & 0.004007 & 0.027270 & 0 & 0.011833 & 2314.774954 & \\
\hline Shrub land area $\left(\mathrm{km}^{2}\right)$ & 0 & 0 & 0.029560 & 0 & 0 & 0.006150 & 0 & 11.451110 & \\
\hline Other woodland area $\left(\mathrm{km}^{2}\right)$ & 0 & 0 & 0.016325 & 0 & 0 & 0 & 0 & 17.162250 & \\
\hline Natural pasture area $\left(\mathrm{km}^{2}\right)$ & 0 & 0 & 0 & 0 & 0 & 0 & 0 & 16.882569 & \\
\hline Other grassland area $\left(\mathrm{km}^{2}\right)$ & 0.000006 & 0.000763 & 0.000981 & 0.000052 & 0.030542 & 0.042939 & 0.009045 & 468.156193 & \\
\hline Scenic spots area $\left(\mathrm{km}^{2}\right)$ & 0 & 0 & 0 & 0 & 0 & 0 & 0 & 0.352124 & \\
\hline Types of land cover composition & 2 & 2 & 4 & 3 & 3 & 3 & 3 & 11 & \\
\hline Biodiversity maintenance function level & 3 & 4 & 3 & 2 & 4 & 1 & 4 & 9 & \\
\hline LCDI index & 0.0001 & 0.0043 & 0.0974 & 0.0135 & 0.0627 & 0.3055 & 0.0291 & 0.5345 & \\
\hline PRLCI index & $2.21 \times 10^{-14}$ & $5.32 \times 10^{-14}$ & $2.25 \times 10^{-10}$ & $7.18 \times 10^{-14}$ & $3.21 \times 10^{-13}$ & $4.71 \times 10^{-11}$ & $2.03 \times 10^{-13}$ & $0.38 \times 10^{-3}$ & \\
\hline
\end{tabular}


The calculation results of the correlation between the biodiversity maintenance function of each green space unit in the 16 green space sample units and the biodiversity maintenance function of the overall green space in the region are shown in Figure 4. Based on the calculation result of $\mathrm{H}_{\mathrm{k}}$ value of each green space sample unit in Figure 4, 16 green space sample units are divided into 3 categories, as shown in Figure 5. If the value range of $H_{k}$ is $[0,30]$, it belongs to the first class. This kind of green space unit has little influence on the biodiversity maintenance function of the overall green space in the region and is suitable for development as construction land. If the value range of $H_{k}$ is [30,70], it belongs to the second class. This kind of green space unit has certain influence on the biodiversity maintenance function of the overall green space in the region and restricts the development into construction land. If the value range of $H_{k}$ is $[70,100]$, it belongs to the third class. This kind of green space unit has a severe impact on the biodiversity maintenance function of the overall green space in the region, and is prohibited from being developed into construction land. For the two application modes set in the above chapters, the simulation results of method application are as follows.

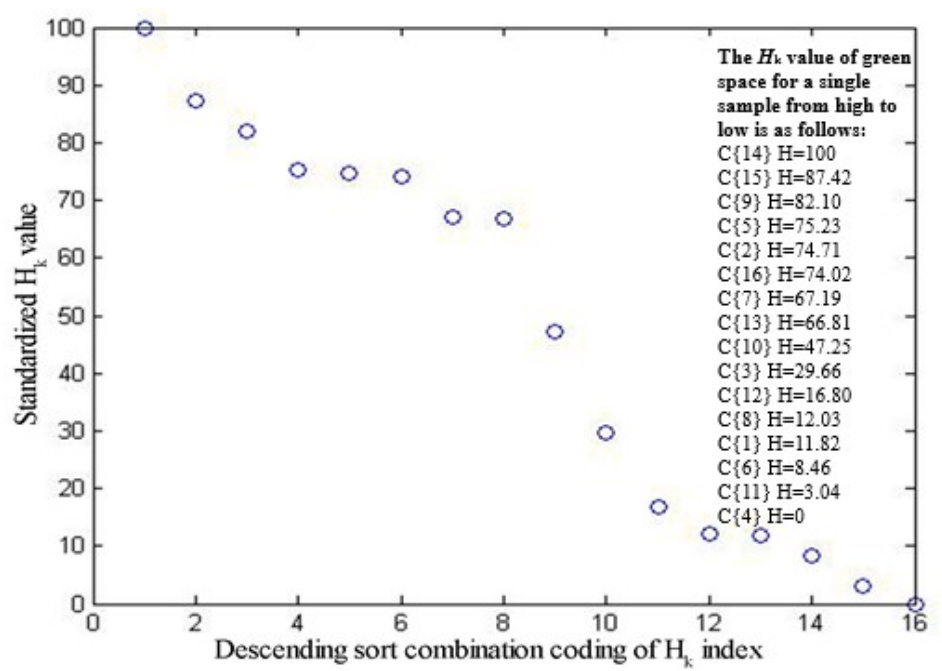

Figure 4. Numerical results of normalized $\mathrm{H}_{\mathrm{k}}$ index for scenario simulation of single green space utilization and protection.

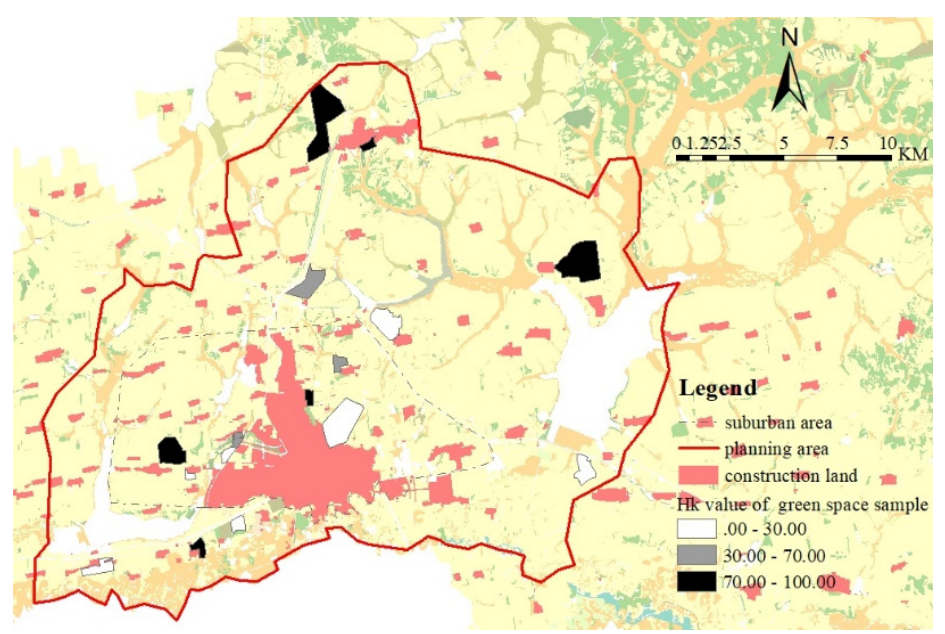

Figure 5. The distribution of the green space sample unit with different $\mathrm{H}_{\mathrm{k}}$ index for simulation of construction site selection.

\subsubsection{Results of Decision Simulation of Single or Multiple Green Space Utilization Modes}

Without considering the actual urban master plan, according to the research results in Figure 4, the construction land development was carried out in one of the 16 green space sample units in the 
urban fringe with the goal of minimizing biodiversity loss. The $H_{\mathrm{k}}$ index of green space unit 4 is only 0 , indicating that the impact of green space unit 4 on the biodiversity maintenance function of the overall green space in the region can be ignored. It can be seen that green space sample unit 4 is the preferred site for the development in the process of site selection of new industrial areas, residential areas or commercial areas in urban fringe areas. From the perspective of minimizing the cost of biodiversity loss, among the 16 green space sample units, the development priority numbers of other green space sample units are $11,6,1,8,12,3,10,13,7,16,2,5,9,15,14$.

Similarly, if $25 \%$ of the total number of sample green spaces is arbitrarily removed for construction land space site selection, then any four of the 16 sample green spaces are removed in the study, and the $H_{\mathrm{k}}$ indexes of all combinations after the four sample green spaces are removed (i.e., The remaining 12 sample green spaces) are calculated, with a total of 1820 combinations, and the corresponding $1820 \mathrm{H}_{\mathrm{k}}$ indexes will be generated. We standardized $1820 \mathrm{H}_{\mathrm{k}}$ indexes and obtained the following results, as shown in Figure 6: After removing the sample green space $\{4 ; 6 ; 11 ; 12\}$, the $H_{\mathrm{k}}$ index is 98.42 , which is less than 100 , indicating that the removal of the sample green space $\{4 ; 6 ; 11 ; 12\}$ will have a weak impact on the biodiversity maintenance function of the overall green space in the region. After the sample green space $\{4 ; 6 ; 8 ; 11\}$ is removed, the $H_{\mathrm{k}}$ value is 100 , indicating that the removal of the sample green space $\{4 ; 6 ; 8 ; 11\}$ will not affect the biodiversity maintenance function of the overall green space in the region. After removing four sample green space units, the sample green space combinations with standardized $H_{\mathrm{k}}$ index higher than 95 are shown in the list in Figure 6 . The impact of the removed green space units in these combinations on the biodiversity maintenance function of the overall green space in the region is almost negligible. Therefore, we can give priority to the use of these green space units according to the actual situation.

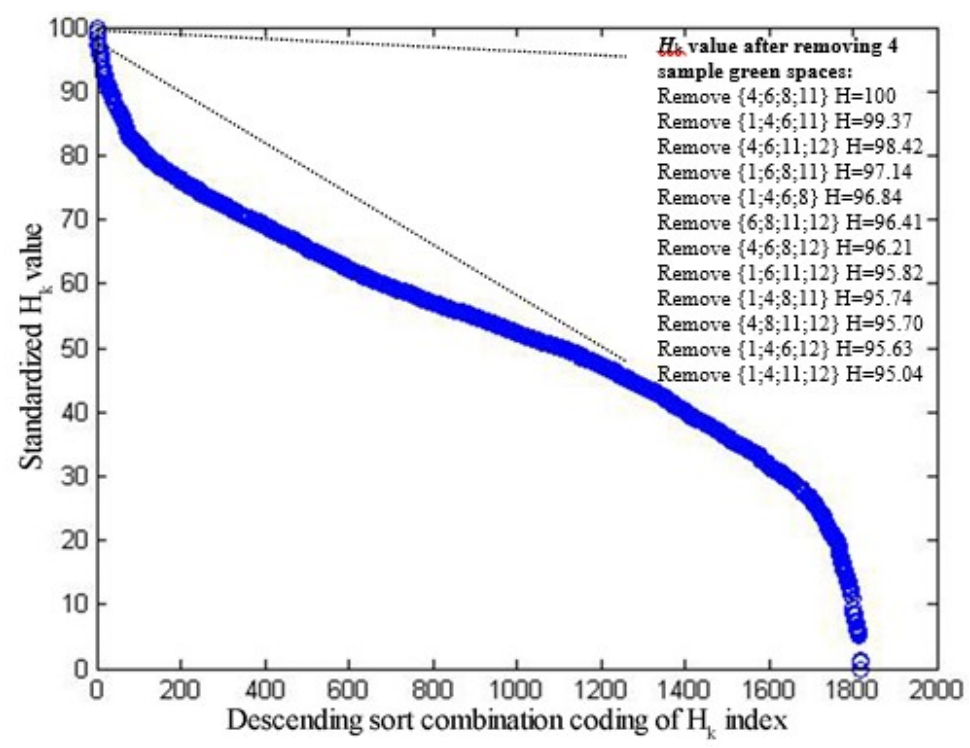

Figure 6. Numerical results of normalized $\mathrm{H}_{\mathrm{k}}$ index for scenario simulation of developing and utilizing 4 green space units simultaneously.

\subsubsection{Results of Decision Simulation of Single or Multiple Green Space Protection Modes}

If the actual urban master plan is not taken into account, according to calculation result of $\mathrm{H}_{\mathrm{k}}$ value of each green space sample unit in Figure 4, it can be seen that the $H_{k}$ index value of the green space unit 14 is 100, indicating that among the current 16 sample space units, the green space unit 14 has the greatest influence on the overall green space biodiversity maintenance function of the region and is the most important for the overall green space biodiversity protection function of the region. Therefore, when making a single green space protection decision, the green space unit 14 should be preferentially selected as the primary protected area. For the currently selected 16 green space sample units, the priority order of protection is green space unit $14>$ green space unit $15>$ green space unit 9 
$>$ green space unit $5>$ green space unit $2>$ green space unit $16>$ green space unit $7>$ green space unit $13>$ green space unit $10>$ green space unit $3>$ green space unit $12>$ green space unit $8>$ green space unit $1>$ green space unit $6>$ green a space unit $11>$ greenspace unit 4 .

For the decision-making situation of multiple green space protection modes, this study plans to select four green space units from 16 green space sample units for the construction of ecological source protection areas. In order to select four green space units that have a significant impact on the biodiversity maintenance function of the overall green space in the region, the study will arbitrarily remove 12 of the 16 green space sample units, and evaluate the correlation between the remaining four green space units and the biodiversity maintenance function of the overall green space in the region. In order to maximize biodiversity conservation, the best green space combinations are $\mathrm{H}_{\{5,9,14,15\}}=100$, $\mathrm{H}_{\{5,14,15,16\}}=98.48, \mathrm{H}_{\{2,5,14,15\}}=98.25, \mathrm{H}_{\{5,7,9,14\}}=97.55$, as shown in Figure 7. Thus, green space units $5,9,14$, and 15 should be listed as priority protection and control objects in the planning of ecological source protection in urban fringe areas.

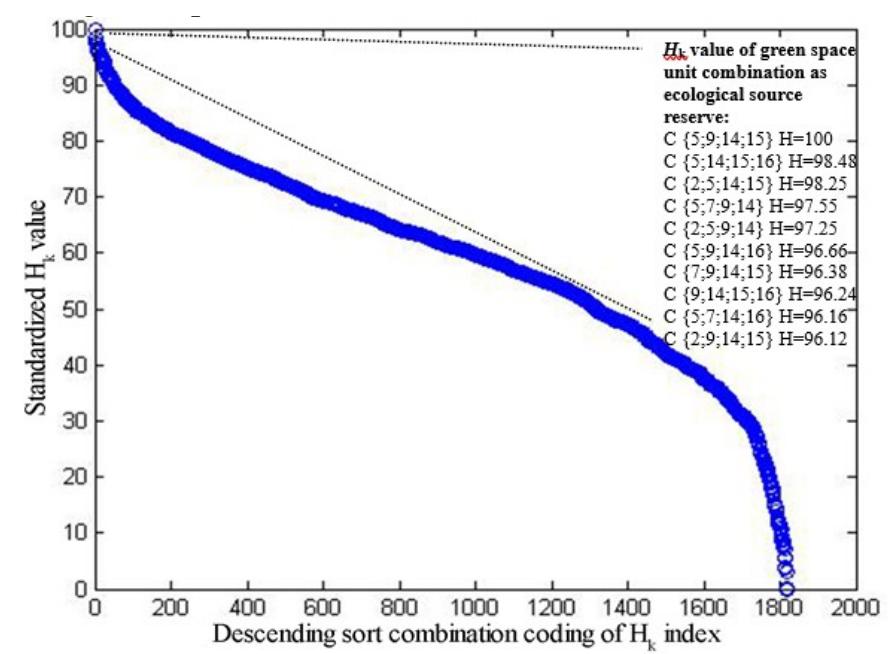

Figure 7. Numerical results of normalized $\mathrm{H}_{\mathrm{k}}$ index for scenario simulation of ecological source protection plan.

Comparing the simulation results with the restricted/forbidden areas in the "Suburban Plan" in the "Beian City Master Plan 2006-2020," the green space units 5, 9, 14, and 15 are not all located in the restricted/forbidden areas. In which the green space units 14 and 15 are located within the restricted/forbidden zone and the green space units 5 and 9 are located within the suitable zone. Thus, when the aim is to maximize the biodiversity conservation and to divide the forbidden zones and to consider the relationship and contribution between the biodiversity maintenance function of the green space unit and the biodiversity maintenance function of the whole green space in the region, this research method has more clearly subdivided the land space of suitable construction areas and restricted/forbidden construction areas in the overall planning, and has more pertinence to the control and protection of green space units.

\section{Discussions and Conclusions}

\subsection{Discussions}

\subsubsection{Practicality and Guidance of the Method}

According to the data of "Suburban Planning" and "Long-Term Planning" in the "Beian City Master Plan 2006-2020," all the land spaces in the downtown vicinity of Beian City are divided into suitable construction areas. In the "Long-Term Planning" (after 2020), green space sample unit 4 is planned as storage land, green space sample unit 5 is planned as residential land, green space sample 
unit 6 is planned as external traffic land, green space sample unit 7 is planned as commercial and financial land and public green area, green space sample unit 8 is planned as scenic area, green space sample unit 9 is planned as public green area, green space sample unit 10 is planned as residential land. Compared with the simulation results of the above single or multiple green space utilization models, it is obvious that not all the green space sample units in the current downtown vicinity are suitable for the construction with the goal of minimizing biodiversity loss. Among them, the $\mathrm{H}_{\mathrm{k}}$ index of green space unit 5 and 9 are both greater than 70, indicating that green space unit 5 and 9 have a greater impact on the biodiversity maintenance function of the overall green space in the region, and green space sample unit 5 is not suitable for residential land development. The $\mathrm{H}_{\mathrm{k}}$ index of green space unit7 and 10 are both greater than 30 and less than 70, indicating that green space units 7 and 10 have a moderate impact on the biodiversity maintenance function of the overall green space in the region, and should be limited to residential land or commercial and financial land. The $\mathrm{H}_{\mathrm{k}}$ index of green space unit 4, 6, and 8 are all less than 30 , indicating that green space units 4,6 , and 8 have little impact on the biodiversity maintenance function of the overall green space in the region, and could be developed as construction land. From the above analysis, it can be further inferred that the impact of construction land development on biodiversity cannot be effectively reduced only based on the suburban planning and long-term planning in "Beian City Master Plan 2006-2020."This research method will make up for the deficiency of suburban planning subdivision in the current master plan. On the basis of suitable subdivision of suburban construction planning, this research further guides the construction planning of green space units in urban fringe areas, so as to effectively reduce the biodiversity loss caused by urban expansion or urban fringe development.

In addition, according to the data of "Suburban Planning" in the "Beian City Master Plan 2006-2020", all the land spaces in the outskirts of Beian City are divided into restricted or prohibited construction areas. Green space units 1, 2, 3, and 11 to 16 belong to ecological conservation area or water source protection area or ecological landscape restoration area, but from a biodiversity conservation perspective, according to decision simulation results of single or multiple green space protection mode, the $H_{\mathrm{k}}$ index of green space unit 1,3,11, and 12 are less than 30 , indicating that green space units 1 , 3,11 , and 12 have little impact on the biodiversity maintenance function of the overall green space in the region, can be used as suitable construction area. However, as a protected area, the restriction or prohibition of its development has little effect on biodiversity maintenance function of the overall region. Therefore, it can be seen that the construction of protected areas cannot achieve the goal of maximization of biodiversity conservation only according to the planning subdivision of "Suburban Planning" in "Beian City Master Plan 2006-2020". When the demarcation of restricted/prohibited areas is aimed at maximizing biodiversity conservation, and the relationship between the biodiversity maintenance function of green space unit and the biodiversity maintenance function of the whole area is considered, the restricted/prohibited areas in the urban master plan can be more clearly subdivided with this method, biodiversity conservation function in restricted/prohibited areas can be more effectively realized, and green space units can be more specifically managed and protected.

\subsubsection{Rationality and Operability of the Method}

In this study, land cover type area, land cover type, LCDI index, PRLCI index and the highest level of biodiversity maintenance function are used as indicators to evaluate the biodiversity maintenance function of each green space unit, and are introduced into Hellwig Method. Based on the ranking of $\mathrm{H}_{\mathrm{k}}$ index, the loss of biodiversity or the degree of conservation are weighed, and then the decision-making is made on the utilization and protection planning of green space in urban fringe areas. The vegetation cover index has the largest weight in the direct assessment of biodiversity maintenance function, with 0.142 , which further verifies the rationality of using land cover type and composition diversity related indicators as indirect indicative indicators of biodiversity maintenance function and applying them to the decision-making method of green space utilization and protection in urban fringe. In addition, this method has a strong operability, compared with other decision-making methods, 
the mathematical model is simple and easy to understand. With the increase of the number of green space sample units, the number of corresponding combinations will increase exponentially, and the computing power and computing amount requirements of computers will gradually increase. Although a series of mathematical calculation processes are relatively complicated, the problem will be easily solved by means of Matlab, Python, and other programming software.

\subsubsection{Adaptability and Universality of the Method}

The basic data used in this study are mainly land cover type data, in the modeling process, the basic data are used objectively, so that the data of land cover type of other cities or regions can also be applied to this model. In addition, only 16 green space sample units were selected to participate in the application simulation study of green space utilization and protection decision-making in urban fringe. There is no theoretical limit on the selection of the number of green space sample units, which can be set according to the actual situation. Finally, limited by the availability of actual species types and quantity data in small towns, this study has obvious advantages in guiding the decision-making of green space utilization and protection in small towns. However, this method is not only applicable to small towns at medium scale, but also applicable to the decision-making of green space utilization and protection at other macro and micro scales. It can be flexibly applied to urban and rural green space utilization or protection planning management decisions.

In order to minimize the loss of biodiversity or maximize biodiversity conservation, this study makes decisions on the selection of green space utilization and protection schemes in urban fringe according to $\mathrm{H}_{\mathrm{k}}$ index ranking, without considering other influencing factors of space utilization and protection. For example, when making the site selection decision for construction land, the original choice may be changed due to the influence of hydro-geological conditions, traffic conditions and other influencing factors. In the planning of ecological source protection, it is necessary to meet the construction and restoration conditions of ecological corridors or ecological networks for selection. For these problems, when choosing green space samples, other influencing factors can be given priority. For example, when making site selection decisions for construction land, the selection of green space samples can be preferentially screened according to land suitability evaluation. In the ecological source protection planning, the selection of green space samples is based on the results of ecological corridor or ecological network construction. We will take the green space unit that meets the conditions as the alternative space unit (i.e., sample space unit). Then, according to this research method, the planning decision of green space utilization or protection in urban fringe is made with the goal of minimizing biodiversity loss or maximizing biodiversity conservation.

\subsection{Conclusions}

Based on the Hellwig Method, this study sorted the $\mathrm{H}_{\mathrm{k}}$ values of different combinations of green space utilization or protection schemes to select the optimal green space utilization or protection scheme for the urban fringe, used the land cover data, and taking the minimization of biodiversity loss or maximization of biodiversity conservation as the principle of green space utilization or protection. Thus, this method can effectively guide the planning decision of green space utilization and the planning decision of green space protection in urban fringe.

In this study, the optimal or most appropriate scheme is selected by comparing the impact of all possible green space utilization or conservation schemes on the biodiversity maintenance function of the whole region. On the one hand, the process can be used to compare the impacts of different schemes on the overall biodiversity loss or conservation of the region. On the other hand, when the green space planning and decision-making process involved in the contradiction between using and protection, this decision method can provide other effective alternatives. While the process of conflict negotiation or resolution may involve more complex and diverse factors than biodiversity loss or conservation. At this point, the absolute answer cannot be given according to the decision-making method. However, on the basis of comprehensive consideration of various influencing factors, it is helpful to choose the 
scheme of minimizing biodiversity loss or maximizing biodiversity conservation from all alternative schemes in this study to achieve urban spatial development at the cost of minimizing ecological and environmental impacts.

Author Contributions: H.L. collected and cleaned all the data and finished the calculation and analyzed the results; Y.M. formed the policy recommendations; Q.L. conceptualized and designed the research and methodology; Y.S. is responsible for future questions from readers as the corresponding author. All authors have read and agreed to the published version of the manuscript.

Funding: This research was supported by the National Nature Science Foundation Project (71874040), the Heilongjiang Province Social Science Foundation Project (18JYB144), and the Heilongjiang Province think-tank project (G093118002). The authors are grateful for the support of the National Nature Science Foundation, the Heilongiiang Province Social Science Foundation, the University of North Carolina at Chapel Hill, and Harbin Engineering University. The contents of this paper are solely the responsibility of the authors and do not represent the official views of the institutes and funding agencies.

Conflicts of Interest: The authors declare no conflict of interest.

\section{References}

1. Secretariat of the Convention on Biological Diversity. Cities and Biodiversity Outlook, Montreal. 2012 , p. 64. Available online: http://www.cbd.int/en/subnational/resources/documents (accessed on 21 February 2019).

2. Schwarz, N. Urban form revisited-selecting indicators for characterizing European cities. Landsc. Urban Plan. 2010, 96, 29-47. [CrossRef]

3. Qiu, J.X.; Wang, X.K.; Lu, F.; Ouyang, X.Y.; Zheng, H. The spatial pattern of landscape fragmentation and its relations with urbanization and socio-economic developments: A case study of Beijing. Acta Ecol. Sin. 2012, 32, 2659-2669.

4. Huang, B.R.; Zhang, H.Z. The relationship between humans and the environment at the urban-rural interface: Research progress and prospects. Acta Ecol. Sin. 2012, 32, 7607-7621. [CrossRef]

5. Wang, P.F. A study on commodification in rural space and the relationship between urban and rural areas in Beijing city. Acta Geogr. Sin. 2013, 68, 1657-1667.

6. Bian, G.M.; Cheng, W. A study on the multi-dimensional optimization of rural industrial space in the fringe areas of big cities. Agric. Econ. 2017, 6, 19-20.

7. Wang, R.F.; Wang, P.F. Theories and practices of rural consumption under post-productivism. J. Cap. Norm. Univ. (Nat. Sci. Ed.) 2017, 38, 91-97.

8. Song, Z.J.; Liu, L.M. Spatial characteristics analysis for multifunctional transition of suburban agricultural areas in Beijing. Sci. Geogr. Sin. 2011, 31, 427-433.

9. Ma, W.Q.; Jiang, G.H.; Li, W.Q.; Zhou, T.; Zhang, R.J. Multifunctionality assessment of the land use system in rural residential areas: Confronting land use supply with rural sustainability demand. J. Environ. Manag. 2019, 231, 73-85. [CrossRef] [PubMed]

10. Ye, L.; Xing, Z.; Yan, W.T. Smart Planning of Urban-Fringe Greenspaces: Core Issues, Conceptual Framework and Planning Strategies. Urban Plan. Forum 2017, 1, 30-38.

11. Fuller, R.A.; Irvine, K.N.; Devine-Wright, P.; Warren, P.H.; Gaston, K.J. Psychological benefits of green space increase with biodiversity. Biol. Lett. 2007, 3, 390-394. [CrossRef]

12. Mitchell, R.; Popham, F. Effect of exposure to natural environment on health inequalities: An observational population study. Lancet 2008, 372, 1655-1660. [CrossRef]

13. Francis, R.A.; Chadwick, M.A. What makes a species synurbic? Appl. Geogr. 2012, 32, 514-521. [CrossRef]

14. Kelcey, J.G. Vertebrates and Invertebrates of European Cities: Selected Non-Avian Fauna; Springer: New York, NY, USA, 2014; p. 580.

15. Adriaensen, F.; Chardon, J.P.; Blust, G.D.; Swinnen, E.; Villalba, S.; Gulinck, H.; Matthysen, E. The application of least-cost modeling as a functional landscape model. Landsc. Urban Plan. 2003, 64, 233-247. [CrossRef]

16. Manes, F.; Incerti, G.; Salvatori, E.; Vitale, M.; Ricotta, C.; Costanza, R. Urban ecosystem services: Tree diversity and stability of tropospheric ozone removal. Ecol. Appl. 2012, 22, 349-360. [CrossRef] [PubMed]

17. Bekessy, S.A.; White, M.; Gordon, A.; Moilanen, A.; Mccarthy, M.A.; Wintle, B.A. Transparent planning for biodiversity and development in the urban fringe. Landsc. Urban Plan. 2012, 108, 140-149. [CrossRef] 
18. Tang, B.S.; Wong, S.W.; Lee, K.W. Green Belt, Countryside Conservation and Local Politics: A Hong Kong Case Study. Rev. Urban Reg. Dev. Stud. 2005, 17, 230-247. [CrossRef]

19. Millward, H. Urban containment strategies: A case-study appraisal of plans and policies in Japanese, British, and Canadian cities. Land Use Policy 2006, 23, 473-485. [CrossRef]

20. Boentje, J.P.; Blinnikov, M.S. Post-Soviet forest fragmentation and loss in the Green Belt around Moscow, Russia (1991-2001): A remote sensing perspective. Landsc. Urban Plan 2007, 82, 208-221. [CrossRef]

21. Dong, Z.J.; Wu, C.F.; Ye, Y.M.; Yang, X. The theory and practice of "Multiple Planning Integration"; Zhejiang University Press: Hangzhou, China, 2017.

22. Hassan, R.; Scholes, R.; Ash, N. Ecosystems and Human Well-Being: Current State and Trends; Island Press: Washington, DC, USA, 2005.

23. Wang, S.Y.; Li, H. Analysis of Shaping the Urban Fringe Greenspace System Based on Landscape Ecology Principles. Urban Dev. Stud. 2015, 22, 20-24.

24. Lu, M.; Qu, Y. Regional Ecological Network Construction Based on Ecosystem Service-A Case Study of Harbin. Chin. Landsc. Archit. 2017, 33, 103-107.

25. McKinney, M.L. Effects of urbanization on species richness: A review of plants and animals. Urban Ecosyst. 2008, 11, 161-176. [CrossRef]

26. Fu, X. Spatial and Temporal Change and Ecosystem Service Response of Urban Green Space in Beijing City. Ph.D. Thesis, Beijing Forestry University, Beijing, China, 2013.

27. Li, Y.Y. The Change of Urban Green Space and Its Impact on Eco-Environmental Effects: A Case Study in Shanghai. Ph.D. Thesis, Fudan University, Shanghai, China, 2012.

28. Gu, C.L.; Chen, T.; Ding, J.H.; Yu, W. The study of the urban fringes in Chinese megalopolises. Acta Geogr. Sin. 1993, 48, 317-328.

29. Zhai, G.Q. The Development and Consrtuction of Urban Fringe of Contemporary Big City in China. Ph.D. Thesis, Tianjin University, Tianjin, China, 2007.

30. Zhou, J.; Xie, B. The related concept discrimination and subject development trend of urban fringe in China and abroad. Urban Plan. Intern. 2014, 4, 14-20.

31. Foley, J.A.; DeFries, R.; Asner, G.P.; Barford, C.; Bonan, G. Global consequences of land use. Science 2005, 309, 570-574. [CrossRef] [PubMed]

32. Walz, A.; Lardelli, C.; Behrendt, H.; Gret-Regamey, A.; Lundstrom, C.; Kytzia, S.; Bebi, P. Participatory scenario analysis for integrated regional modelling. Landsc. Urban Plan. 2007, 81, 114-131. [CrossRef]

33. Nelson, G.C.; Bennett, E.; Berhe, A.A.; Cassman, K.; DeFries, R.; Dietz, T.; Dobermann, A.; Dobson, A.; Janetos, A.; Levy, M.; et al. Anthropogenic drivers of ecosystem change: An overview. Ecol. Soc. 2006, 11, 29. Available online: http://www.ecologyandsociety.org/vol11/iss2/art29/ (accessed on 21 February 2019). [CrossRef]

34. Costanza, R.; D’Arge, R.; Groot, R.D.; Farber, S.; Grasso, M.; Hannon, B.; Limburg, K.; Naeem, S.; O’Neill, R.V.; Paruelo, J.; et al. The value of the world's ecosystem services and natural capital. Nature 1997, 387, 253-260. [CrossRef]

35. Wang, Z.M.; Zhang, B. Evolution analysis of land use structure of Songnen plain based on GIS and information entropy: In terms with disorder degree, complexity and diversity. Syst. Sci. Compr. Stud. Agric. 2005, 21, 196-200.

36. Fu, B.J.; Chen, L.D. Landscape diversity types and their ecological significance. Acta Geogr. Sin. 1996, 51, 454-462.

37. Verburg, P.H.; Van De Steeg, J.; Veldkamp, A.; Willemen, L. From land cover change to land function dynamics: A major challenge to improve land characterization. J. Environ. Manag. 2009, 90, 1327-1335. [CrossRef]

38. Metzger, M.J.; Rounsevell, M.D.A.; Acosta-Michlik, L.; Leemans, R.; Schroter, D. The vulnerability of ecosystem services to land use change. Agric. Ecosyst. Environ. 2006, 114, 69-85. [CrossRef]

39. Chen, X.P.; Chen, W.B. Construction and evaluation of ecological network in Poyang Lake Eco-economic Zone, China. Chin. J. Appl. Ecol. 2016, 27, 1611-1618.

40. Li, J.; Zhu, Y.M.; Zhang, H.; Zhang, G.J. Dynamic recognition of source area of landscape ecological security pattern in Beidaihe New District. Res. Soil Water Conserv. 2016, 23, 340-351.

41. Yang, S.S.; Zou, C.X.; Shen, W.S.; Shen, R.P.; Xu, D.L. Construction of ecological security patterns based on ecological red line: A case study of Jiangxi Province. Acta Ecol. Sin. 2016, 35, 250-258. 
42. Xu, F.; Yin, H.W.; Kong, F.H.; Xu, J.G. Developing ecological networks based on MASP and the least-cost path method: A case study in Bazhong western new district. Acta Ecol. Sin. 2015, 35, 6425-6434.

43. Wu, J.S.; Zhang, L.Q.; Peng, J.; Feng, Z.; Liu, H.M.; He, S.B. The integrated recognition of the source area of the urban ecological security pattern in Shenzhen. Acta Ecol. Sin. 2013, 33, 4125-4133.

44. Kong, F.H.; Yin, H.W. Developing green space ecological networks in Jinan City. Acta Ecol. Sin. 2008, 28, 1711-1719.

45. Psomas, A.; Dagalaki, V.; Panagopoulos, Y.; Konsta, D.; Mimikou, M. Sustainable agricultural water management in Pinios river basin using remote sensing and hydrologic modeling. Procedia Eng. 2016, 162, 277-283. [CrossRef]

46. Panagopoulos, Y.; Makropoulos, C.; Mimikou, M. Theories and practices of rural consumption under post-productivism. Environ. Model. Softw. 2012, 30, 57-70. [CrossRef]

47. Urban, D.L.; Minor, E.S.; Treml, E.A.; Schick, R.S. Graph models of habitat mosaics. Ecol. Lett. 2009, 12, 260-273. [CrossRef]

48. Lu, M.; Liu, Q. Study on the identification of urban aquatic ecological network based on Archydro hydrological model: Taking "Sponge City" Ji'nan as an example. Urban Dev. Stud. 2016, 23, 26-32.

49. Guo, S.; Saito, K.; Yin, W.D.; Su, C. Landscape Connectivity as a Tool in Green Space Evaluation and Optimization of the Haidan District, Beijing. Sustainability 2018, 10, 1979. [CrossRef]

50. Li, Z.M.; Fan, Z.X.; Shen, S.G. Urban Green Space Suitability Evaluation Based on the AHP-CV Combined Weight Method: A Case Study of Fuping County, China. Sustainability 2018, 10, 2656. [CrossRef]

51. Guzman, L.A.; Escobar, F.; Peña, J.; Cardona, R. A cellular automata-based land-use model as an integrated spatial decision support system for urban planning in developing cities: The case of the Bogotá region. Land Use Policy 2020, 92, 1-13. [CrossRef]

52. Hellwig, Z. Toward a System of Quantitative Indicators of Components of Human Resources Development; UNESCO: Paris, France, 1968.

53. Łopucki, R.; Kiersztyn, A. Urban green space conservation and management based on biodiversity of terrestrial fauna-A decision support tool. Urban For. Urban Green. 2015, 14, 508-518. [CrossRef]

54. Xie, G.D.; Zhen, L.; Lu, C.X.; Xiao, Y.; Chen, C. An ecosystem service value method based on expert knowledge. J. Nat. Resour. 2008, 23, 911-919.

55. Bai, Y.C. Analysis of land carrying capacity of changshan islands based on ecological footprint. China Sci. Technol. Inf. 2009, 14, 19-20. 